\title{
PENDAMPINGAN PEMANFAATAN LIMBAH BOTOL PLASTIK SEBAGAI BAHAN TAMBAH PEMBUATAN PAVING DI KELURAHAN ARJOWINANGUN KECAMATAN KEDUNGKANDANG KOTA MALANG
}

\author{
Mohammad Erfan ${ }^{1}$, Sriliani Surbakti ${ }^{2}$, Nenny Roostrianawaty ${ }^{3}$ \\ 1,2,3Prodi Teknik Sipil,Fakultas Teknik Sipil dan Perencanaan, ITN Malang
}

\begin{abstract}
ABSTRAK
Pertambahan jumlah penduduk tentunya menghasilkan pertambahan jumlah volume sampah organik dan anorgaik. Salah satu sampah yang dihasilkan masyarakat di Kelurahan Arjowinangun adalah sampah organik dan sampah anorganik, dimana sampah atau limbah organik dan limbah anorganik apabila tidak dilakukan pengolahan tentunya jumlah volume sampah akan semakin bertambah dan mengakibatkan terjadinya dampak pencemaran terhadap lingkungan, yaitu terjadinya penurunan sanitasi lingkungan. Berdasarkan kondisi eksisting maka permasalahan yang Kelurahan Arjowinangun adalah banyaknya tumpukan sampah aorganik dan sampah anorganik sehingga mengakibatkan terjadinya pencemaran lingkungan khususnya penurunan sanitasi lingkungan di sekitar permukiman dan terjadinya penyumbatan pada saluran drainase akibat masuknya sampah ke dalam saluran draianse. Oleh sebab itu dari permasalahan yang ada di lokasi mitra maka perlu dilakukan upaya mengurangi permasalahan pengurangan jumlah volume khususnya penanganan pemanfaatan sampah anorganik yaitu, salah satunya adalah pemanfaatan limbah botol plastik sebagai tambahan bahan konstruksi ringan sebagai pembuatan paving. Sehingga dari pemanfaatan limbah atau sampah anorganik yaitu limbah botol plastik maka diharapkan akan mengurangi jumlah volume sampah yang dibuang ke tempat pembuangan akhir sampah (TPA). Hasil dari pengolahan limbah botol plastik tersebut akan menghasilkan menjadi paving dan pendampingan mitra ini akan melibatkan masyarakat di Kelurahan Arjowinangun untuk memanfaatkan limbah botol plastik menjadi barang yang bernilai tinggi dan berguna serta berwawasan lingkungan.
\end{abstract}

Kata Kunci: Paving; Limbah Plastik, Wirausaha.

\section{PENDAHULUAN}

Meningkatnya pertumbuhan kota serta pertambahan jumlah penduduk tentunya akan menghasilkan pertambahan jumlah volume sampah dan sampah tersebut akan mengakibatkan sumber pencemaran lingkungan, pencemaran tanah, pencemaran air, dan terjadinya penyumbatan saluran air yang menyebabkan suatu kota akan menimbulkan banjir apabila tidak dikelola dengan baik. Sesuai dengan Undang-undang N0.32 Tahun 2009 tentang perlindungan dan pengelolaan lingkungan hidup maka masyarakat, pengusaha, dan industri berkewajiban memelihara kelestarian fungsi lingkungan, dan mengurangi pencemaran 
lingkungan. Dengan demikian, permasalahan persampahan atau limbah padat organik dan limbah padat anorganik yang ada diperkotaan perlu dilakukan penanggulangan melalui pemanfaatan sampah sistem daur ulang. Disisi lain sampah juga merupakan potensi sumber daya yang dapat dimanfaatkan sehingga mempunyai nilai tambah sebagai produk daur ulang maupun pruduk baru yang menghasilkan pendapatan masyarakat perkotaan. Secara geografis Kelurahan Arjowinangun terletak dibagian selatan Kecamatan Kedungkandang yang memiliki luas $266 \mathrm{Km} 2$ yang merupakan perkotaan yang jumlah penduduknya cukup besar yaitu 29.250 jiwa, tentunya dari kepadatan jumlah penduduk akan menghasilkan jumlah volume sampah yang cukup besar. Kelurahan Arjowinangun memiliki permasalahan sampah yang cukup besar dan sering terjadinya tumpukan sampah di beberapa rumah penduduk sehingga menimbulkan pencemaran lingkungan, tentunya untuk mengurangi permasalahan di Kelurahan Arjowinangun maka diperlukan upaya pemanfaatan sampah perkotaan baik sampah organik maupun sampah anorganik.

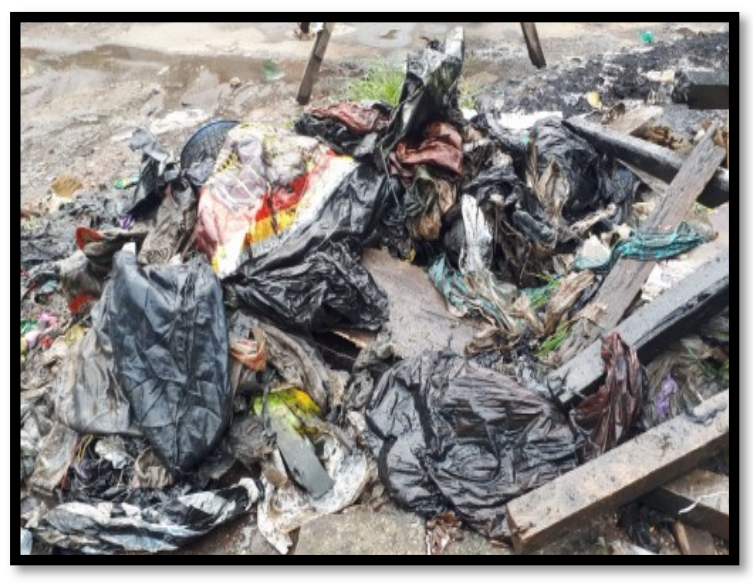

Gambar 1. Profil Kondisi Tumpukan Sampah Yang Belum Terangkut ke TPS

Salah satu upaya pemanfaatan sampah perkotaan di Kelurahan Arjowinangun yaitu lebih diperioritaskna kepada pemanfaatan sampah atau limbah botol plastik sebagai bahan tambahan konstruksi ringan untuk dijadikan paving. Dalam pengolahan limbah botol plastik tersebut tentunya berpotensi terhadap mitra untuk mengajak partisipasi masyarakat serta melatih masyarakat membuka peluang usaha secara swakelola masyarakat yang menghasilkan pendapatan masyarakat. Adapun teknologi bahan dalam pembuatan paving dengan campuran limbah plastik tentunya sangat berdampak dalam mengurangi pencemaran lingkungan dari limbah plastik. Oleh karena itu diperlukan masyarakat yang produktif melalui keterlibatan masyarakat dalam pembuatan paving dengan kadar plastik yang sesuai dengan hasil penelitian dan dari hasil pengolahan limbah botol plastik ini akan menambah menjadi barang yang bernilai tinggi dan berguna serta berwawasan lingkungan.

\section{Permasalahan Mitra}

Permasalahan dengan mitra di Kelurahan Arjowinangun yaitu :

1. Banyaknya tumpukan sampah atau limbah padat organik dan limbah padat anorganik yang belum terkelola dengan baik sehingga menyebabkan terjadinya pencemaran lingkungan di sekitar permukiman,

2. Pada saat musim hujan mengakibatkan tersumbatnya saluran drainase akibat masuknya sampah ke dalam saluran drainase sehingga mengakibatkan terjadinya banjir

3. Penurunan sanitasi terhadap lingkungan sekitar permukiman warga. 


\begin{tabular}{l} 
JURNAL SONDIR \\
$p-I S S N$ 1979-2832 \\
$e-I S S N ~ 2746-8275$ \\
\hline
\end{tabular}

https://ejournal.itn.ac.id/index.php/sondir vol.5 No.1 Tahun 2021, pp. 13-23

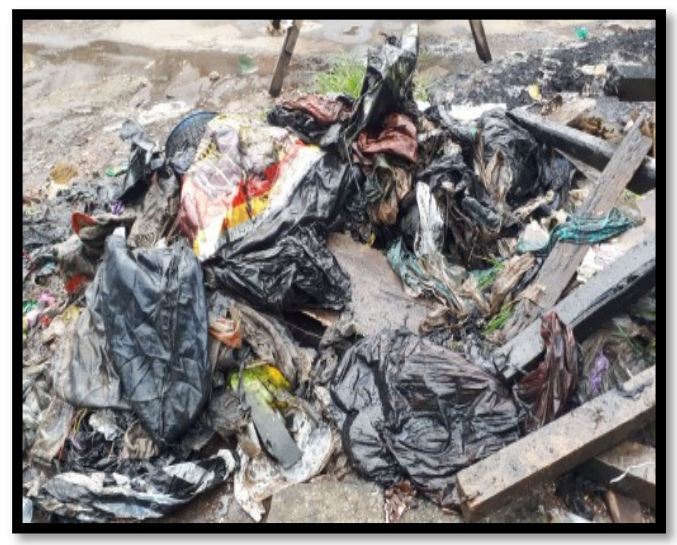

Gambar 2. Kondisi Tumpukan Sampah Yang Belum Terangkut ke TPS

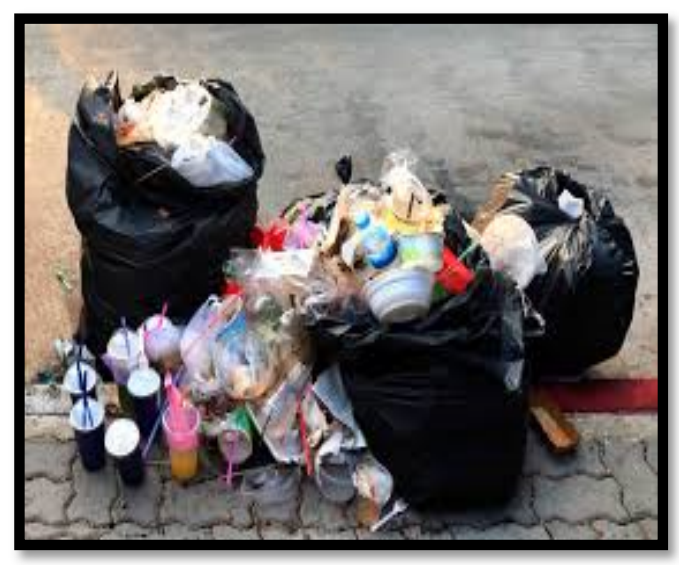

Gambar 3. Kondisi Tumpukan Sampah Yang Belum Terangkut ke TPS

Sehingga berawal dari permasalahan dari mitra maka diperlukan pendampingan dalam mengurangi jumlah volume limbah plastik dengan cara memanfaatkan limbah botol plastik sebagai tambahan bahan ringan konstruksi untuk dijadikan paving bahan tambah Pembuatan Paving di Kelurahan Arjowinangun Kecamatan Kedungkandang Kota Malang, sehingga dapat menambah pendapatan masyarakat dengan memanfaatkan sampah menjadi suatu produk yang berdaya jual tinggi serta dapat juga mengurangi pencemaran sanitasi lingkungan sekitar permukiman warga.

\section{SOLUSI DAN TARGET LUARAN}

\section{Solusi}

Berdasarkan permasalahan dengan mitra di Kelurahan Arjowinangun yaitu :

1. banyaknya tumpukan sampah atau limbah padat organik dan limbah padat anorganik yang belum terkelola dengan baik sehingga menyebabkan terjadinya pencemaran lingkungan di sekitar permukiman,

2. Pada saat musim hujan mengakibatkan tersumbatnya saluran drainase akibat masuknya sampah ke dalam saluran drainase sehingga mengakibatkan terjadinya banjir

3. Penurunan sanitasi terhadap lingkungan sekitar permukiman warga.

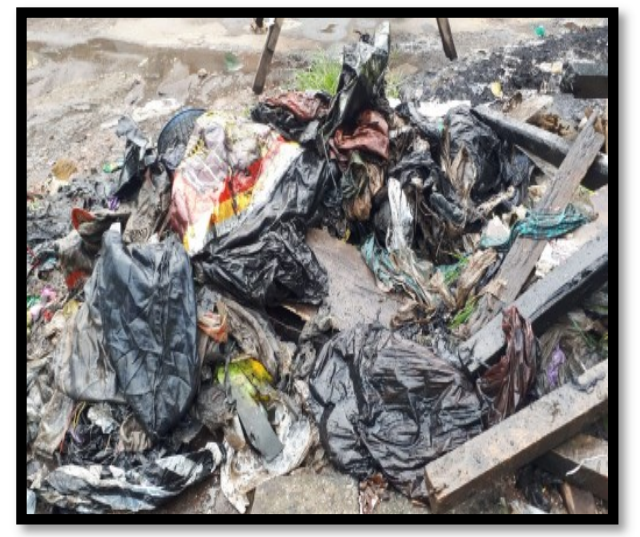

Gambar 2. Kondisi Tumpukan Sampah Yang Belum Terangkut ke TPS

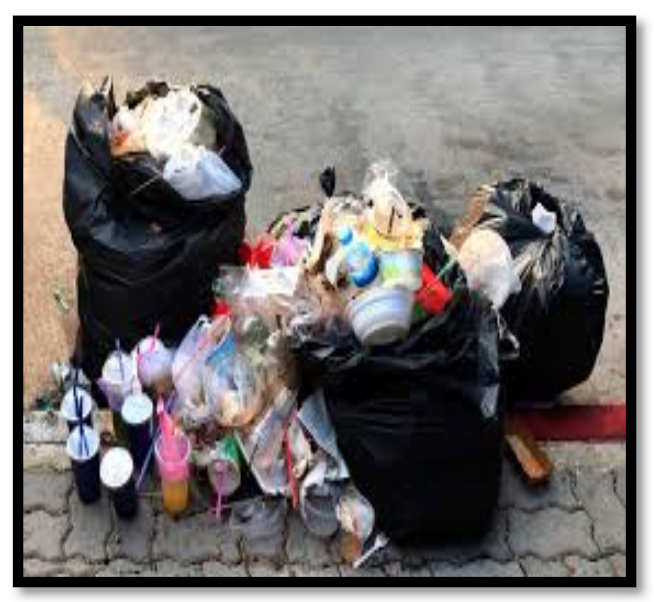




\section{JURNAL SONDIR \\ p-ISSN 1979-2832 \\ e-ISSN 2746-8275}

https://ejournal.itn.ac.id/index.php/sondir

vol.5 No.1 Tahun 2021, pp. 13-23

Gambar 2. Kondisi Tumpukan Sampah Yang Belum Terangkut ke TPS

Sehingga dengan adanya permasalahan tersebut yang mengakibatkan terjadinya pencemaran lingkungan di sekitar permukiman maka Tim pengabdian masyarakat memberikan pendampingan kepada masyarakat di Kelurahan Arjowinangun yakni dengan memanfaatkan limbah botol plastik yang bertujuan untuk untuk mengurangi sampah atau limbah sampah plastik/ sampah anorganik dilokasi mitra. Oleh sebab itu maka Tim pendampingan memberikan solusi kepada masyarakat di Kelurahan Arjowinangun, yaitu :

1. Pendekatan melalui sosialisasi lewat diskusi antara warga di Kelurahan Arjowinangun dan TIM Abdimas ITN Malang dalam keterlibatannya untuk seluruh rangkaian kegiatan mulai dari penentuan dan perencanaan materi dan pelaksanaan program kegiatan.

2. Memanfaatkan teknologi tepat guna dengan memanfaatkan limbah botol plastik sebagai tambahan bahan ringan konstruksi untuk dijadikan paving Bahan Tambah Pembuatan Paving.

3. Pelatihan dan pendampingan secara langsung melibatkan warga dan Tim Abdimas ITN Malang dalam proses pembuatan paving sebagai sarana aplikasi ilmu pengetahuan untuk meningkatkan pengetahuan warga.

\section{MATERI DAN METODE}

\section{PELAKSANAAN}

\section{Materi}

Materi pendampingan pemanfaatan limbah botol pastik sebagai tambahan bahan ringan konstruksi untuk dijadikan Paving di Kelurahan Arjowinangun yaitu dengan memberikan sosialisasi kepada masyarakat yang dibantu oleh beberapa mahasiswa
Fakultas Teknik Sipil Institut Teknologi Nasional (ITN) Malang. Metode sosialisai yang digunakan ada 2 yaitu Metode Ceramah dan Metode Pendampingan (Workshop). Metode ceramah yaitu diskusi dan tanya jawab yang digunakan untuk menyampaikan informasi tentang pengolahan limbah menjadi paving blok.

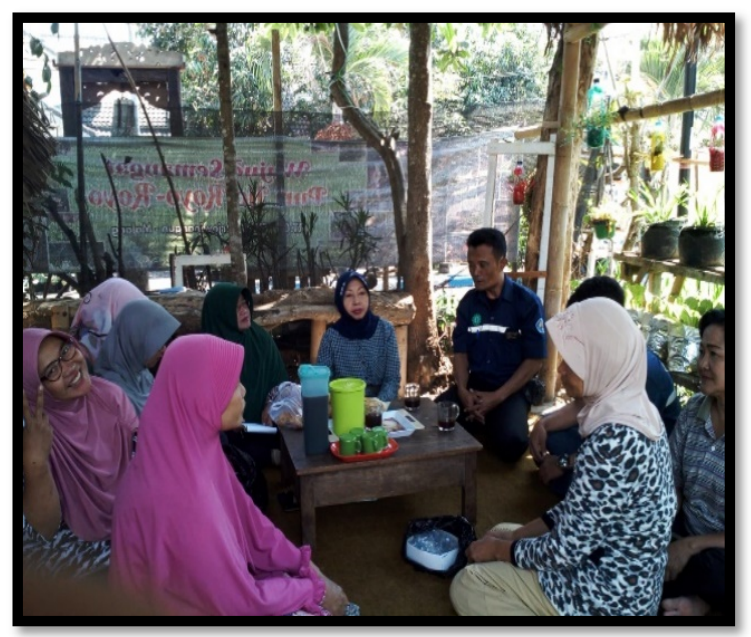

Gambar 4. Metode Sosialisasi Ceramah dan Pendampingan Kepada Warga

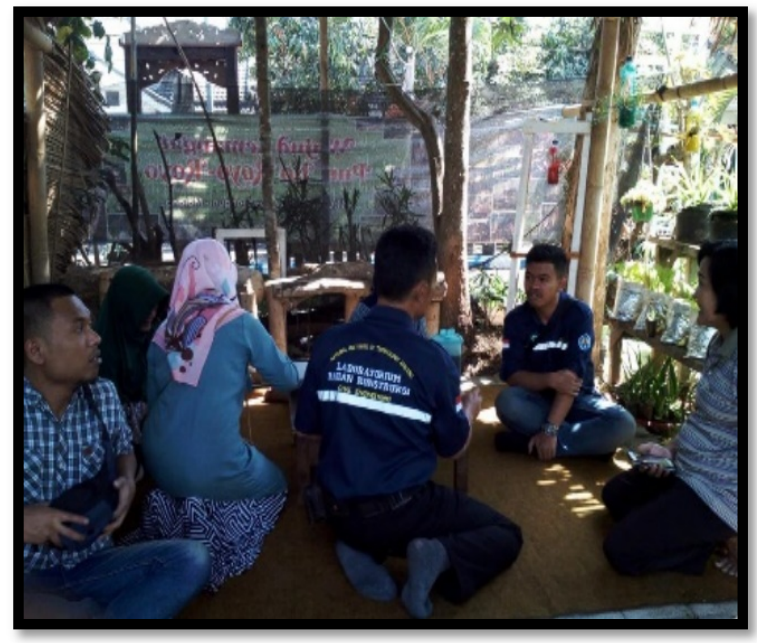

Gambar 5. Metode Sosialisasi Ceramah dan Pendampingan Kepada Warga dan Dibantu Beberapa Mahasiswa Teknik Sipil ITN Malang 


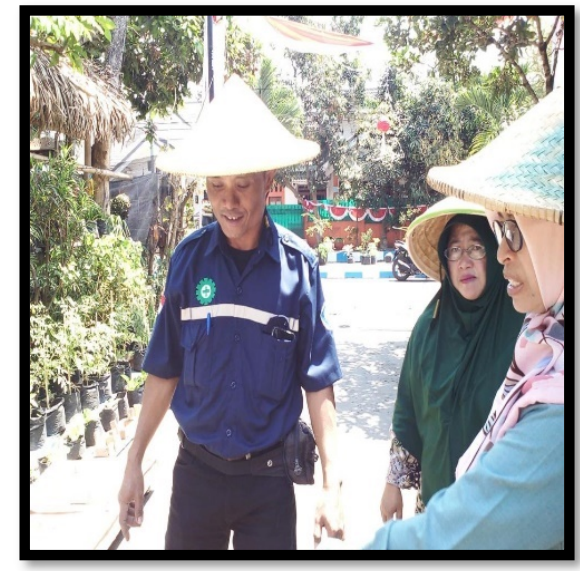

Gambar

6. Memberikan Pendampingan Pembuatan Paving dari Limbah Botol Plastik

Metode Pendampingan yaitu bersifat konsultatif tentang pembuatan paving blok dari limbah plastik. Dengan adanya sosialisasi ini diharapkan dapat menambah pengetahuan serta membuka pikiran mahasiswa untuk memanfaatkan limbah menjadi bahan dengan nilai jual dan nilai guna yang lebih tinggi. Paving blok yang berbahan dasar limbah plastik dapat dijadikan salah satu produk untuk wirausaha. Jiwa kewirausahaan harus dibentuk sejak dini untuk menumbuhkan rasa kemandirian pada kalangan remaja khususnya mahasiswa yang memiliki kemampuan yang lebih besar untuk menciptakan ide dan inovasi dengan berbagai sumber di era digital 4.0 dapat memanfaatkan paving blok yang ramah lingkungan sebagai produk bernilai jual lebih tinggi.

\section{Metode Pelaksanaan}

Pelaksanaan pembuatan paving dari bahan limbah botol plastik dapat di lihat bagan alir berikut.
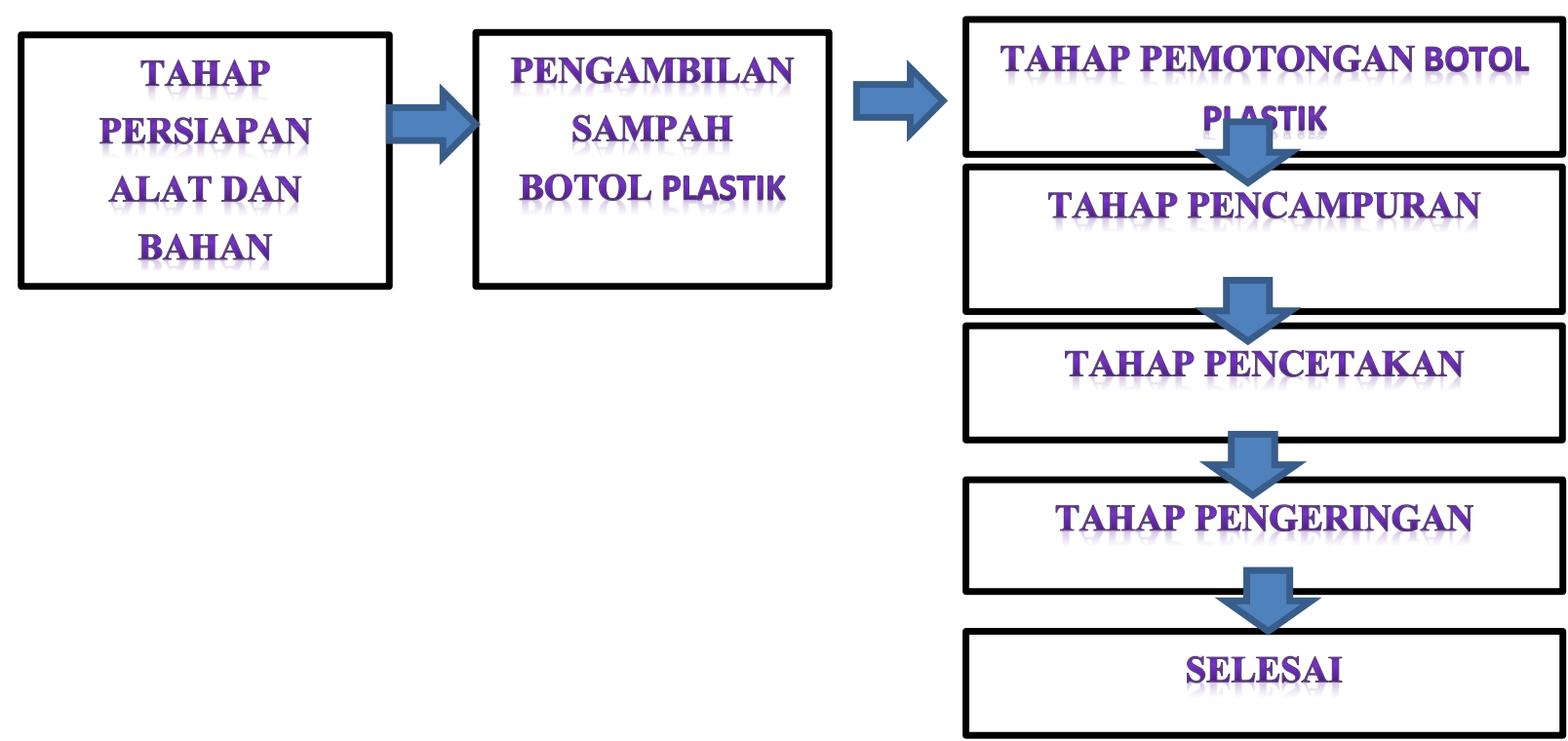

Gambar 7. Bagan tahap pelaksanaan pembuatan paving dari bahan limbah botol plastik

Metode pelaksanaan pembuatan paving dari limbah botol plastik adalah:

\section{Tahap persiapan alat dan bahan}

Tahap ini meliputi persipan alat dan bahan yang akan digunkan pada saat proses pembuatan paving yang berbahan dasar sampah atau limbah botol plastik. Limbah padat botol plastik ini berfungsi untuk 
JURNAL SONDIR

p-ISSN 1979-2832

e-ISSN 2746-8275

https://ejournal.itn.ac.id/index.php/sondir

vol.5 No.1 Tahun 2021, pp. 13-23

memperkuat paving apabila sudah diolah dan paving

tidak mudah pecah.

\section{Adapun penyiapan alat adalah:}

1. Alat pengaduk menggunakan molen dengan kapasitas $50 \mathrm{~kg}$ semen.

2. Alat tampungan campuran.

3. Alat cetakan paving

4. Cetok dan alat pemadat.

\section{Sedangkan bahan-bahan yang digunakan diantaranya :}

1. Limbah botol plastik

2. Pasir atau abu batu

3. Semen yang digunakan yang bertipe PPC atau PCC.

4. Air bersih (PDAM) secukupnya

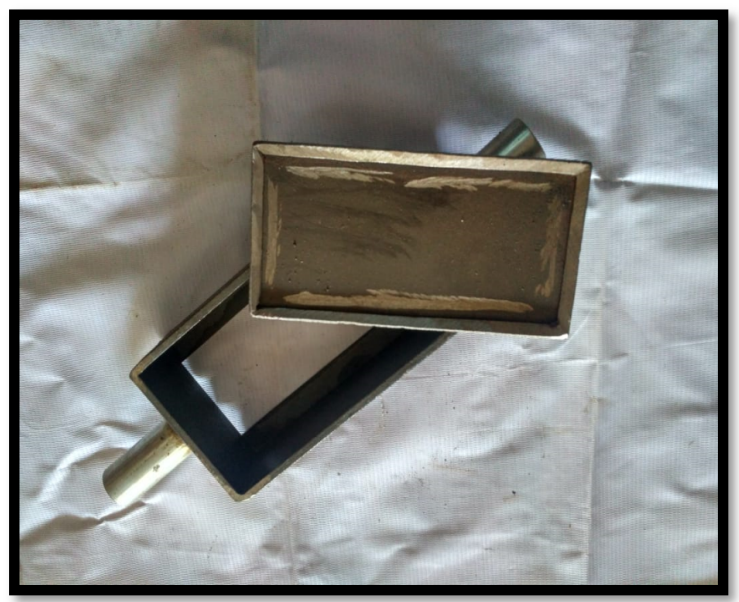

Gambar 8. Cetak Paving

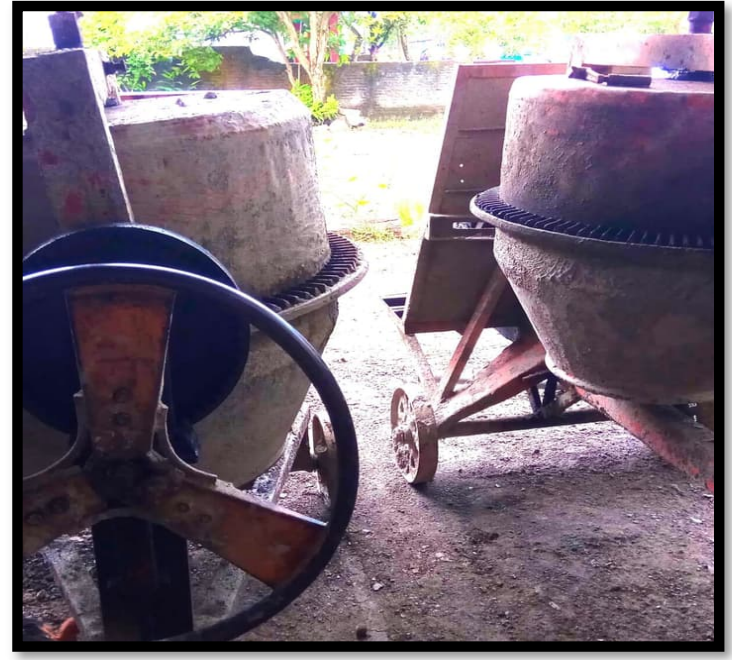

Gambar 9. Molen Alat Pengaduk

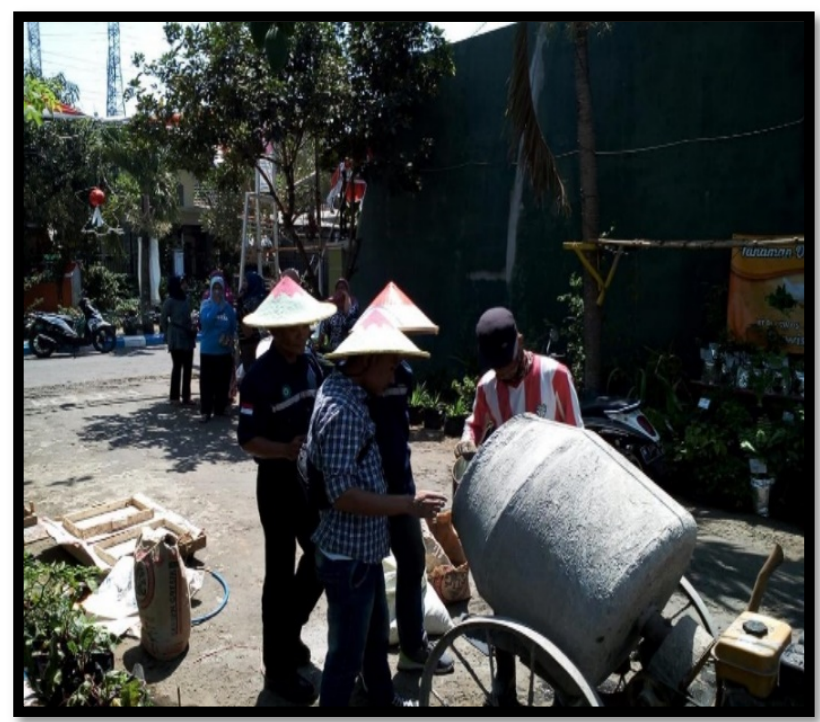

Gambar 10. Alat Pengaduk Limbah Botol Plastik

Yang Sudah Dicacah Menggunakan Molen 


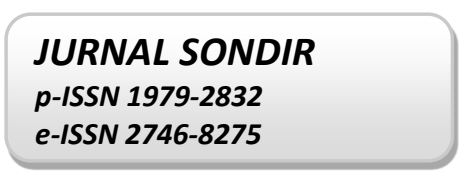

https://ejournal.itn.ac.id/index.php/sondir

vol.5 No.1 Tahun 2021, pp. 13-23

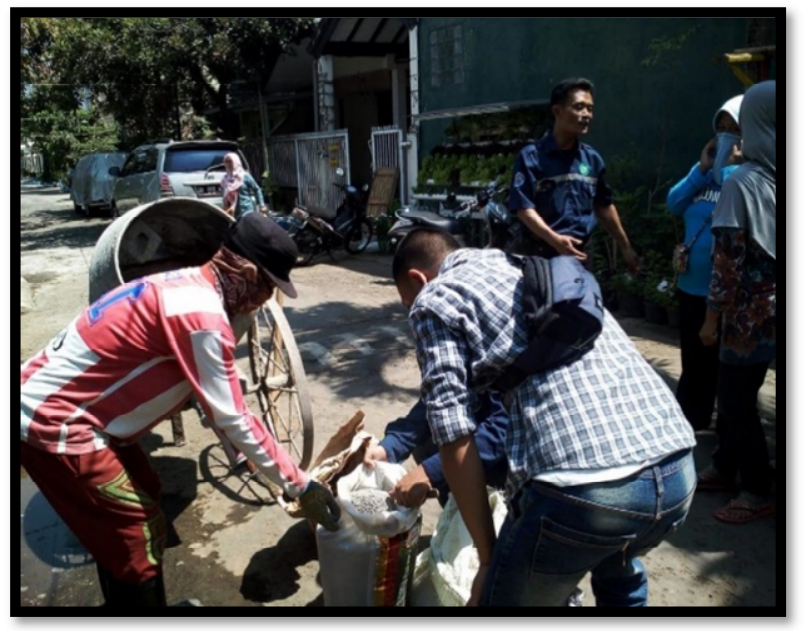

Gambar 11. Pendampingan Kepada Masyarakat

Yang Dibantu Beberapa Mahasiswa Pada Proses

Pengadukan

\section{Tahap pengambilan sampah / limbah botol plastik}

Tahap ini dilakukan pengumpulan sampah/ limbah botol plastik ( botol mineral, maupun botol minuman lainnya).

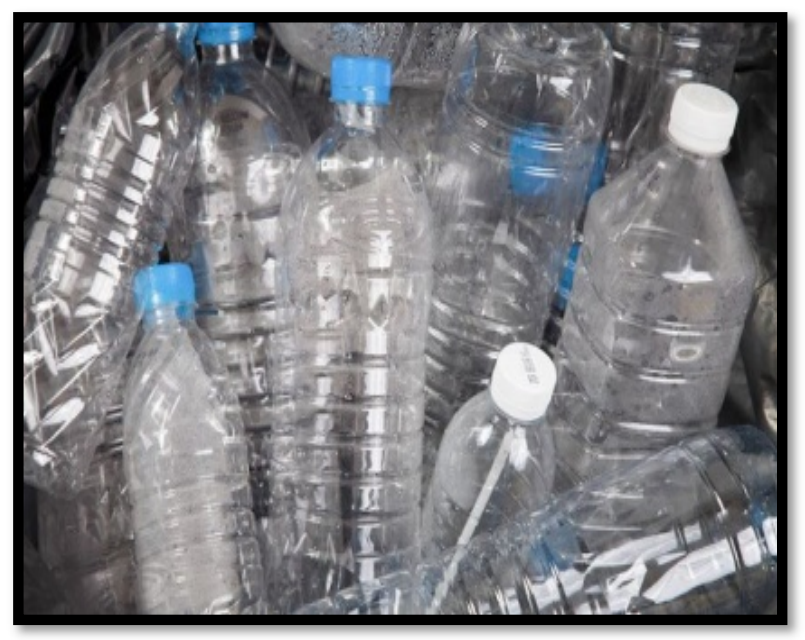

Gambar 12. Limbah Botol Plastik

\section{Tahap Pemotongan}

Limbah/sampah botol plastik yang sudah dikumpulkan kemudian dicacah atau dipotong dipotong-potong dengan ukuran lebar antara 5-10 $\mathrm{mm}$ dan panjang antara $10-15 \mathrm{~mm}$.

\section{Tahap Pencampuran}

Tahap ini dilakukan pencampuran dari bahan-bahan yang sudah dikumpulkan, yaitu:

1. Saat mesin pengaduk menyala pertama memasukkan air secukupnya.

2. Setelah beberapa saat dimasukkan potongan botol plastik ke dalam mesin pengaduk.

3. Selanjutnya dimasukkan semen diteruskan memasukkan pasir atau abu batu.

4. Pengadukan supaya merata, pengadukan dibiarkan beberapa \pm 15 menit.

5. Sebelum campuran dituang, di cek apakah campuran terlalu encer apa tidak. Untuk mengetahui keenceran, diambil sedikit campuran untuk di uji slum (uji penurunan).

6. Kalau keenceran sudah cukup, maka campuran yang ada di mesin pengaduk dituang ke tempat yang sudah disediakan.

7. Selanjutnya campuran dimasukkan kedalam cetakan paving sambil dipadatkan dengan alat penumbuk.

8. Dilakukan penjemuran yang sudah dimasukkan ke dalam cetakan paving sampe \pm 15 menit, hal ini supaya campuran yang sudah tercetak tidak langsung hancur (melebur).

\section{Tahap Pencetakan}

Tahap ini pencampuran bahan-bahan yang sudah masuk ke dalam mesin pengaduk selanjutnya dituangkan ke dalam cetakan paving kemudian diratakan setiap permukan hingga padat. 


\section{JURNAL SONDIR \\ p-ISSN 1979-2832 \\ e-ISSN 2746-8275}

https://ejournal.itn.ac.id/index.php/sondir

vol.5 No.1 Tahun 2021, pp. 13-23

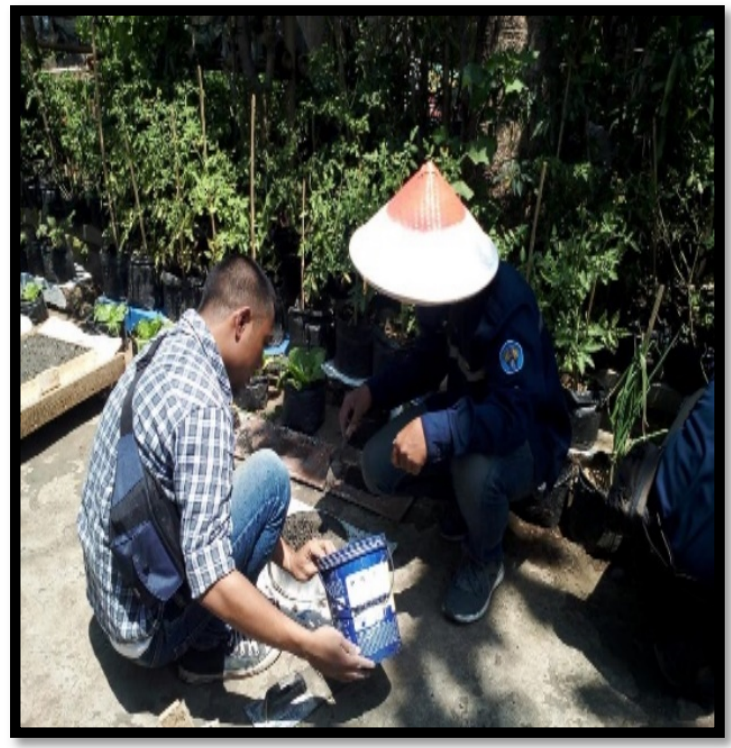

Gambar 13. Tahap Pencetakan Paving

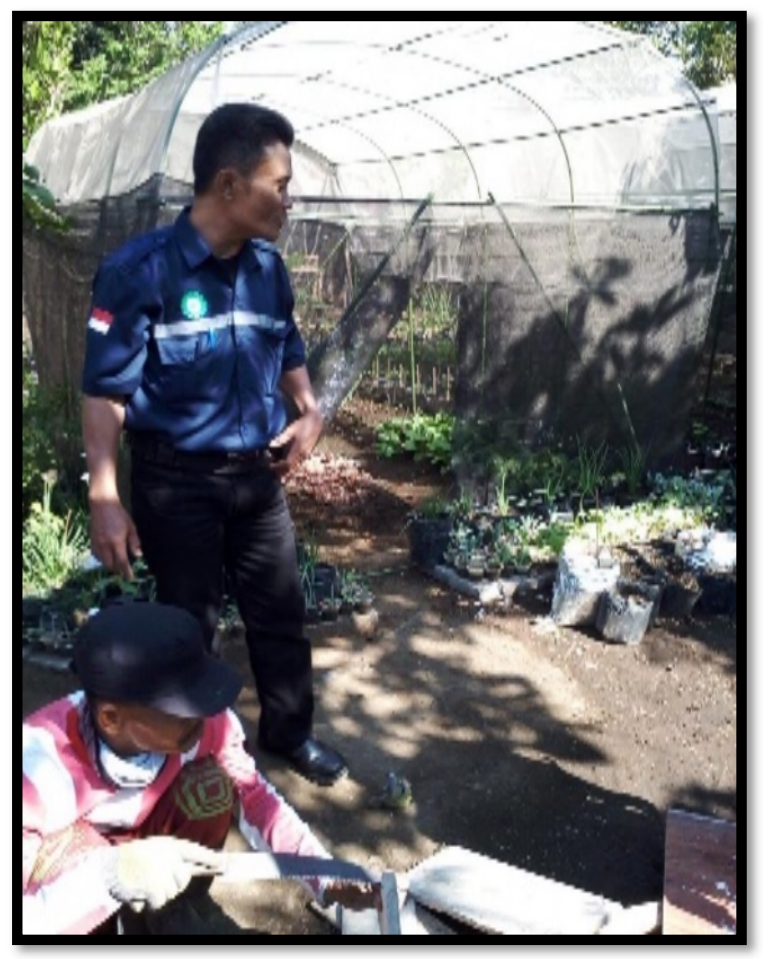

Gambar 14. Tahap Pencetakan Paving

\section{Tahap Pengeringan}

Setelah selesai pencetakan maka dilakukan pengeringan selama \pm 15 menit kemudian dilakukan pelepasan paving dari alat cetakan.

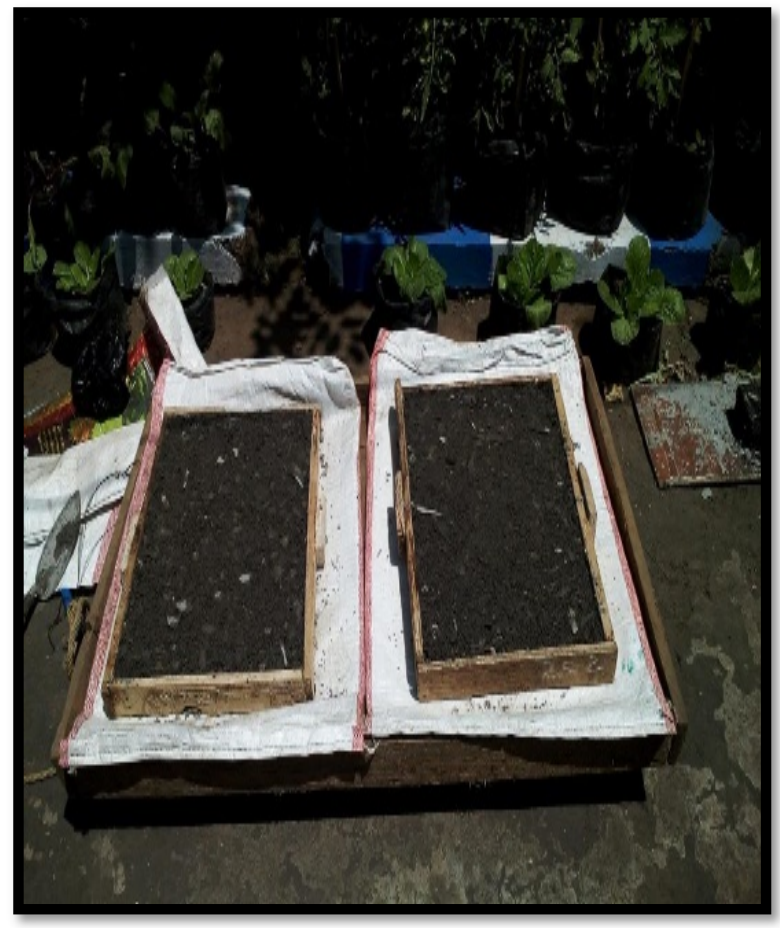

Gambar 15. Tahap Pengeringan

\section{HASIL DAN PEMBAHASAN}

Berdasarkan permasalahan yang telah diuraikan sebelumnya maka solusi permasalah yang telah dilaksanakan di lokasi kegiatan adalah dengan memberikan sosialisasi kepada warga Arjowinangun yang dibantu beberapa mahasiswa Fakultas Teknik Sipil ITN Malang dengan "Pemanfaatan Limbah Plastik Sebagai Bahan Dasar Pembuatan Paving Blok Untuk Menumbuhkan Jiwa Kewirausahaan Pada Kalangan masyarakat".

Sosialisasi dilakukan untuk memberikan gambaran kepada mahasiswa sebagai kalangan milenial bahwa ada solusi untuk menangani masalah pencemaran lingkungan dengan memanfaatkan ilmu pengetahuan dan teknologi yang dimiliki dalam membuat suatu produk yang memiliki nilai guna dan nilai jual yang lebih tinggi. Permasalahan lingkungan yang diatasi adalah dengan memanfaatkan sampah plastik atau limbah plastik menjadi bahan dasar pembuatan paving blok. 
Setelah selesai menerima materi dalam sosialisasi kemudian warga dan mahasiswa diarahkan untuk melihat proses pembuatan paving blok dengan bahan dasar limbah botol plastik. Praktek pembuatan dilakukan dengan melihat alat dan barang apa saja yang dibutuhkan dan melihat proses pembuatannya. Setelah itu melihat produk hasilnya berupa paving blok yang berbahan dasar limbah plastik. Pendampingan dan PKM ini dilakukan agar masyarakat dan mahasiswa memiliki pandangan bahwa untuk memulai berwirausaha tidak selalu dengan modal dan bahan yang besar, tetapi dapat memanfaatkan barang disekitar mereka dan dapat menghasilkan barang yang memiliki nilai guna dann nilai jual yang lebih tinggi dengan proses yang tidak sulit. Sehingga diharapkan dapat menumbuhkan jiwa kewirausahaan dalam diri masyarakat dan PKM.

Berdasarkan permasalahan yang telah diuraikan sebelumnya maka pelaksana aan pemberian materi melalui sosialisasi kepada masyarakat dan PKM dapat membangun jiwa Wirausaha pada kalangan Milenial pada Era Digital 4.0. Jiwa kewirausahaan harus ditumbuhkan sejak dini agar dapat mengatur pola pikir kalangan milenial dan sekaligus dapat memotivasi PKM untuk memulai berpikir dan mencari solusi dalam berwirausaha. Pemberian contoh produk yang murah dan mudah dilakukan untuk memulai wirausaha dilakukan saat sosialisasi agar warga Kelurahan Arjowinangun mendapat pandangan pembuatan produk tidaklah sulit. Salah satu contoh produk yang diambil adalah pembuatan paving blok berbahan dasar limbah plastik Pembuatan paving blok berbahan dasar limbah plastik juga dilakukan untuk memberikan pengetahuan tambahan kepada masyaraka dan PKM bahwa terdapat produk yang gampang dan mudah diproduksi dalam dunia teknik sipil. Setiap alat dan proses pembuatan diperlihatkan sampai pada hasil akhir yaitu paving blok. Antusias dan semangat dari warga dan mahasiswa dalam mengikuti sosialisasi. Serta dapat mengurangi jumlah volume sampah yang ramah lingkungan dilokasi mitra dan mengkader masyarakat menjadi produktif sehingga dapat menambah pendapatan masyarakat dengan memanfaatkan sampah menjadi suatu produk yang berdaya jual tinggi.

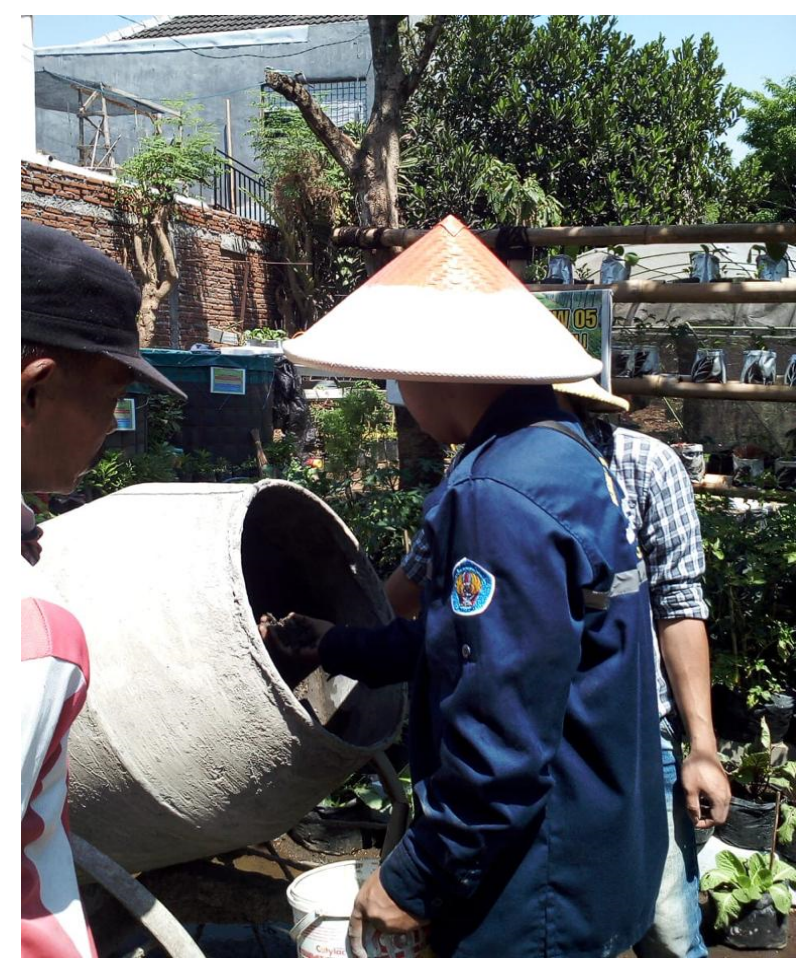

Gambar 16. Proses Pengaduk Limbah Botol Plastik 


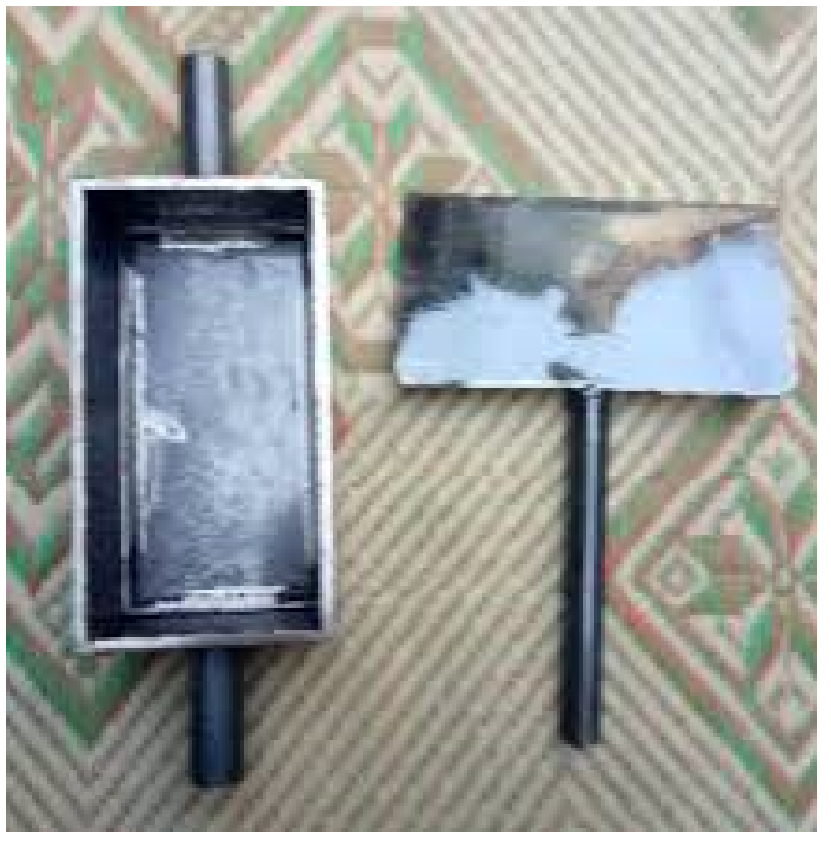

Gambar 17. Cetakan Paving

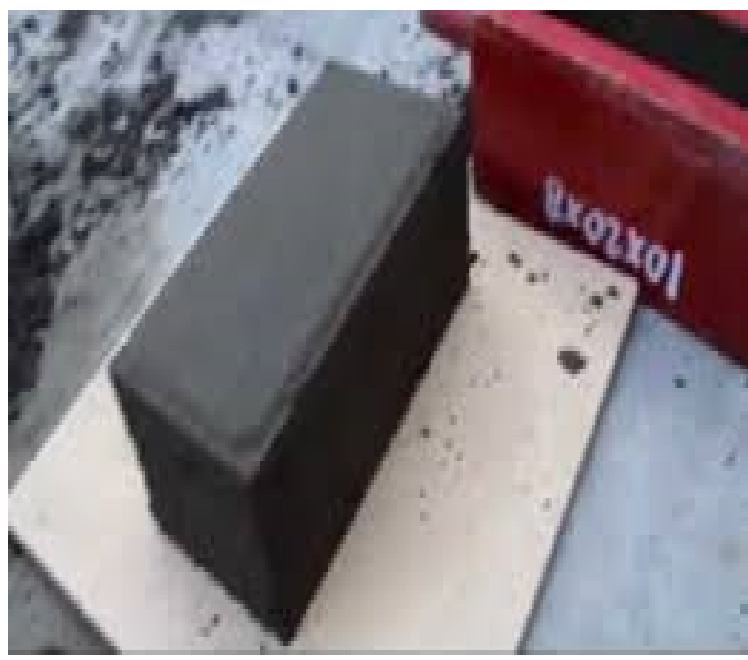

Gambar 18. Hasil Paving yang Sudah Dicetak

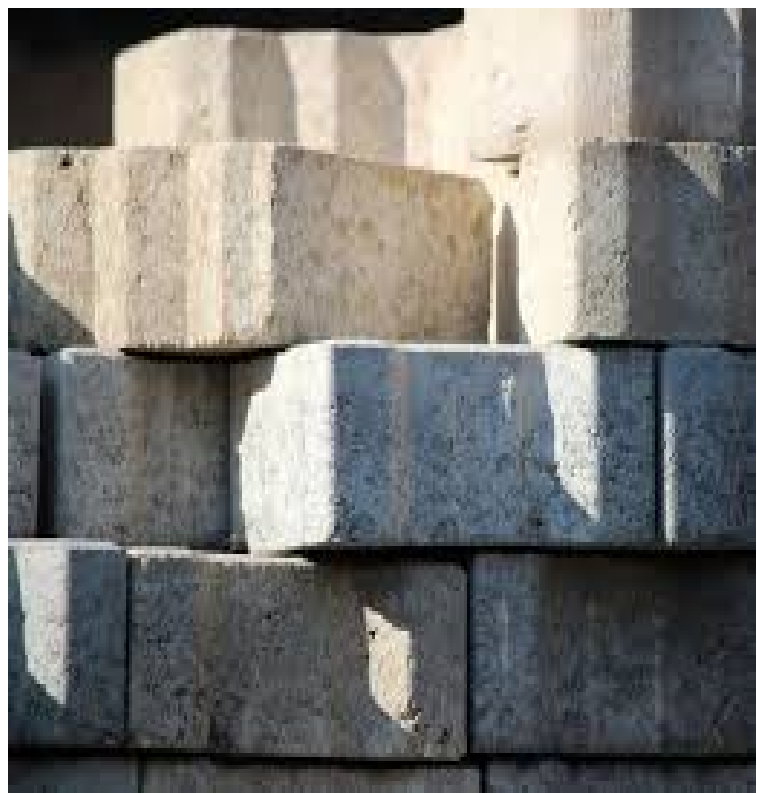

Gambar 19. Hasil Paving yang Sudah Dicetak

Dari hasil proses pengolahan limbah botol plastik menjadi Paving yang di lakukan Tim ITN Abdimas ITN Malang kepada warga Kelurahan Arjowinangun sudah memberikan dampak yang positip bagi warga baik dari segi ilmu pengetahuan terhadap warga, dapat mengurangi jumlah volume sampah, dan memiliki nilai jual yang dapat menambah nilai jual dan nilai guna yang lebih tinggi.

\section{KESIMPULAN DAN SARAN}

\section{Kesimpulan}

Dari kegiatan pendampingan kegiatan pengabdian masyarakat ITN Malang dengan Mitra warga Kelurahan Arjowinangun memberikan dampak positip terhadap Mitra, yaitu dapat mengurangi jumlah volume sampah, hasil proses pemanfaatan limbah botol plastik yang diolah menghasilkan produk Paving, dan menambah nilai jual dan nilai guna yang lebih tinggi.

\section{Saran}


Memanfaatkan ilmu pengetahuan yang diproleh dari Tim Pendampingan Abdimas ITN Malang agar dapat menambah wawasan warga serta dapat memasarkan Paving tersebut melalui media sosial maupun dipasarkan melalui koprasi, sekolahan, atau kantor.

\section{DAFTAR PUSTAKA}

Burhanuddin B. dan MRS Darmanijati. 2018.

$$
\begin{aligned}
& \text { Pemanfaatan Limbah Plastik Bekas } \\
& \text { Untuk Bahan Utama Pembuatan } \\
& \text { Paving Block. Jurnal Rekayasa } \\
& \text { Lingkungan Vol. 18/No.1/April } 2018 .
\end{aligned}
$$

Deloitte Indonesia Prespective. 2019. Generasi

Milenial Dalam Industri 4.0: Berkah

Bagi Sumber Daya Manusia Indonesia Atau Ancaman.

Pambudi Sunarsihanto. 2019. dalam Deloitte Indonesia Prespective. Generasi Milenial Dalam Industri 4.0: Berkah Bagi Sumber Daya Manusia Indonesia Atau Ancaman.

Sofiana, Y. 2010. Pemanfaatan Limbah

Plastik Sebagai Alternatif Bahan Pelapis

(Upholstery) Pada Produk Inte 